\title{
STANDAR OPERASIONAL DAN PROSEDUR PERANGKAT BANTU ELEKTRONIK KUMBUNG JAMUR
}

\author{
Muji Sukur' ${ }^{1}$, Arief Jananto ${ }^{2}$, Teguh Khristianto ${ }^{3}$ \\ ${ }^{1,2,3}$ Program Studi Sistem Informasi, Fakultas Teknologi Informasi, Universitas Stikubank \\ e-mail: ${ }^{1}$ msukur@edu.unisbank.ac.id, ${ }^{2}$ ajananto@edu.unisbank.ac.id, \\ 3 teguhkhris@edu.unisbank.ac.id
}

\begin{abstract}
Abstrak
Pengelolaan jamur tiram memang masih memiliki komoditas andalan bagi peningkatan ekonomi masyarakat. Namun beragam kendala telah menghadapkan petani pembudidaya dengan berbagai upaya penerapan teknologi kekinian. Salah satunya adalah pengendalian dan pengelolaan area kumbung jamur dengan pengaturan teknologi elektronik. Perlunya penerapan standar operasional dan prosedur guna mendukung penerapan teknologi ini sebagai salah satu upaya pendekatan kondisi alamiah diharapkan akan memberikan dampak yang signifikan terhadap produktifitas budidaya yang berkelanjutan dan tidak mengenal musim. Beberapa standar yang diterapkan adalah penggunaan perangkat elektronik dengan merek "UNOUMI" telah terimplementasi dan mampu mendukung pembudiaya di berbagai lokasi seperti Pati, Malang, Semarang, Tegal dan Ambarawa.
\end{abstract}

Kata kunci: arduino, jamur tiram, mikrokontroler

\section{PENDAHULUAN}

Jamur tiram masih menjadi salah satu fokus pertanian hortikultura yang memiliki potensi peningkatan tiap tahun produksinya. Potensi ini tidaklah berjalan dengan mulus, namun banyak kendala yang menghadang hingga petani pembudidaya merasakan perubahan yang signifikan untuk memperpanjang pembudidayaan jamur tiram ini. Fenomena alam seperti suhu, kelembaban, lokasi, polutan, operasional harian yang tidak sesuai prosedur dan operasional, serta kemampuan para pembudidaya yang beragam dan tidak seragam.

Sebuah penelitian sebelumnya telah mampu menjembatani perubahan fenomena alamah ini yang memang sangatlah sulit untuk diprediksikan, sehingga kondisi ini menjadi kendala utamanya. Untuk itu diperlukan pendekatan teknologi kekinian yang diharapkan mampu mengurangi celah dan menjembatani peramsalahan para petani pembudidaya jamur tiram ini.

Pengendalian dan pengelolan yang terpadu dengan menggunakan teknologi terapan ini diperlukan guna menjaga produktifitas budidaya jamur tiram ini. Untuk itu diperlukan juga sebuah standar produksi dan standar operasional pengelolan terkait dengan penggunakan perangkat bantu elektronik ini.

\section{STANDARISASI PENGELOLAAN}

Munculnya pendekatan standarisasi ini merupakan upaya yang dirumuskan berdasarkan pada kondisi riil di lapangan yang teranalisa secara teknis guna mendukung penerapan teknologi kekinian dengan menggunakan perangkat bantu elektronik kendali terpadu. Beberapa fokus standarisasi sistem diantaranya adalah sebagai berikut:

a. SOP perangkat UNOUMI A
1) Terpasang di posisi ketinggian $2,5 \mathrm{~m}$
2) Terpasang di posisi tengah kumbung jamur
3) Terpasang 20-30 titik sprayer
4) Pompa RO 100 psi 24 volt
5) Perangkat sprayer pada ketinggian $3,5-4,5 \mathrm{~m}$ 
6) Terpasang 3 lajur saluran sprayer (kiri - tengah - kanan)

b. SOP perangkat UNOUMI B

1) Terpasang di posisi ketinggian $2,5 \mathrm{~m}$

2) Terpasang di posisi tengah kumbung jamur

3) Terpasang 30-60 titik sprayer

4) Pompa RO 100 psi 24 volt (2 buah)

5) Perangkat sprayer pada ketinggian $3,5-4,5 \mathrm{~m}$

6) Terpasang 4 lajur saluran sprayer (1 kiri - 2 tengah -1 kanan)

c. SOP desain kumbung jamur A
1) Kapasitas 1000 - 5000 baglog
2) Ukuran ruang $24-80 \mathrm{~m}$ persegi ( $4 \mathrm{~m} \times 6 \mathrm{~m}$ hingga $8 \mathrm{~m} \times 10 \mathrm{~m}$ )
3) Ketinggian optimal 3,5-4,5 m
4) Jarak antar rak $0,75 \mathrm{~m}$
5) Jarak susunan baglog 0,50 m sebanyak 4 sub rak
6) Sirkulasi udara yang cukup
7) Intensitas cahaya 300 lumens
8) Kelembaban 70-80\%
9) Suhu 26 derajat Celcius

d. SOP desain kumbung jamur B
1) Kapasitas $5000-10000$ baglog
2) Ukuran ruang $24-80 \mathrm{~m}$ persegi ( $8 \mathrm{~m} \times 10 \mathrm{~m}$ hingga $10 \mathrm{~m} \times 15 \mathrm{~m}$ )
3) Ketinggian optimal 3,5-4,5 m
4) Jarak antar rak $0,75 \mathrm{~m}$
5) Jarak susunan baglog $0,50 \mathrm{~m}$ sebanyak 4 sub rak
6) Sirkulasi udara yang cukup
7) Intensitas cahaya 300 lumens
8) Kelembaban 70-80\%
9) Suhu 26 derajat Celcius

\section{STANDAR INSTALASI PERANGKAT ELEKTRONIK}

Pengujian sistem dilakukan dengan pemantauan selama 3 bulan dan terakit pada rangkaian tersimulasi sebagai berikut:

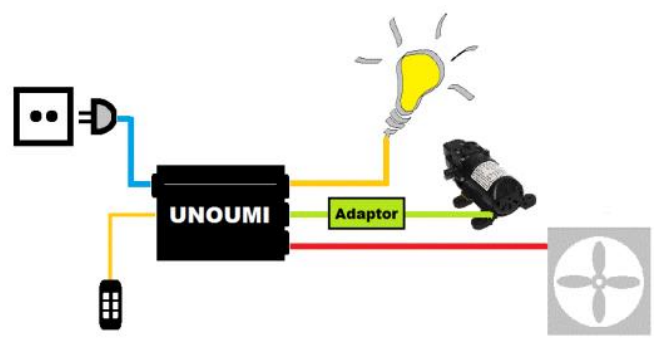

Gambar 1. Rangkaian Standar Uji Implementasi Sistem UNOUMI

Skema rangkaian guna menggambarkan implementasi standar sistem pada area kumbung jamur mitra petani budidaya untuk beberapa daerah yang memiliki perbedaan geografis, yaitu penempatan di area Tegal dan Malang.

Standar sistem ini terdiri dari:
a. Mesin pompa DC 12 volt
b. Perangkat UNOUMI
c. Lampu penerangan
d. Kipas exhaust/kipas angin 
e. Efektif untuk ruang kumbung ukuran sedang

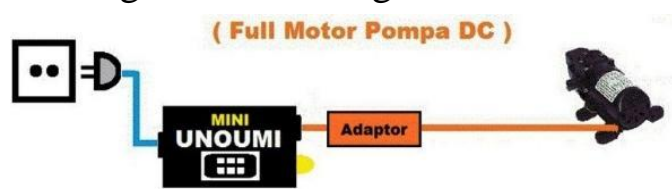

Gambar 2. Rangkaian Standar Standar mini UNOUMI dengan 1 motor DC

Instalasi standar mini UNOUMI dengan 1 motor DC di atas terdiri dari set lengkap sistem yaitu:

a. Mesin pompa DC 12 volt

b. Perangkat mini UNOUMI

c. Efektif untuk ruang kumbung kecil

d. Efisien daya listrik

e. Penggunaan indikator lampu LED pada perangkat mini UNOUMI
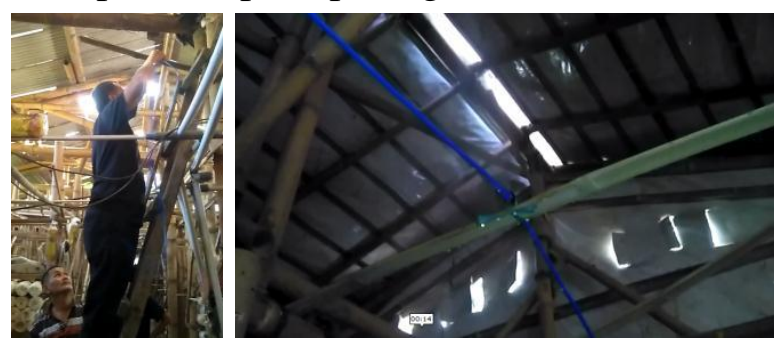

Gambar 3. Perakitan Alat Sesuai Standar Uji Implementasi Sistem

Penerapan standar instalasi biasanya dalam set alat lengkap beserta alat sprayer dan elemen pendukungnya, dimana elemen ini harus sesuai dengan peruntukannya dan penerapan instalasinya.

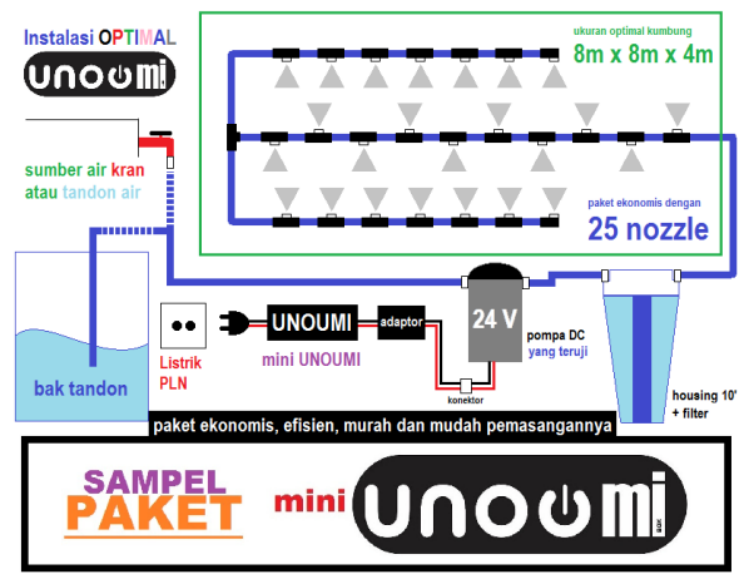

Gambar 4. Sampel Standar Instalasi mini UNOUMI set lengkap

Perakitan instalasi pada gambar di atas dimaksudkan untuk penerapan sistem dengan kriteria standar elemen lengkapnya sebagai berikut:
a. Sprayer 25 nozzle 0.3 micron
b. Mesin pompa RO DC 24 volt
c. Perangkat mini UNOUMI
d. Filter set dan housingnya 0.3 micron
e. Efektif untuk ruang kumbung ukuran $8 \mathrm{~m}$ x $8 \mathrm{~m}$ x $4 \mathrm{~m}$ 


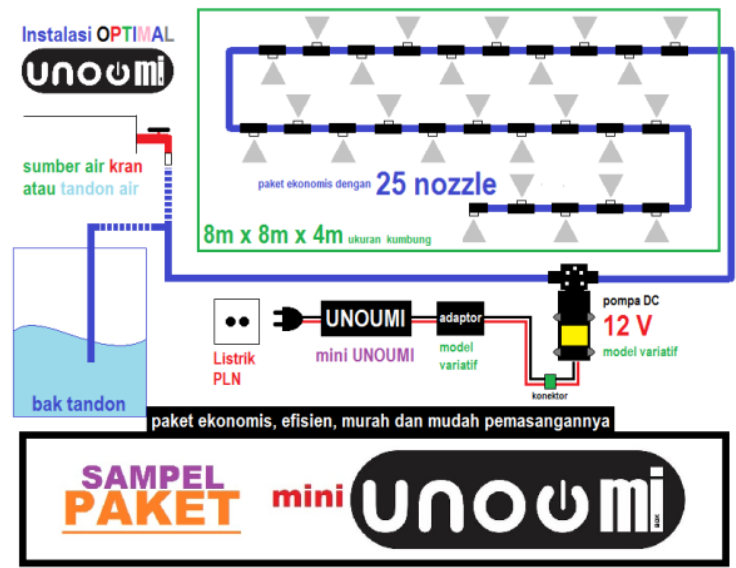

Gambar 5. Sampel Standar Instalasi alternatif mini UNOUMI

Mode alternatif dalam perakitan instalasi pada gambar di atas dimaksudkan untuk memberikan model lain pada penerapan sistem, dengan kriteria standar elemen lengkapnya sebagai berikut:

a. Sprayer 25 nozzle 0.3 micron

b. Mesin pompa DC 12 volt

c. Perangkat mini UNOUMI

d. Filter set dan housingnya 0.3 micron

e. Efektif untuk ruang kumbung ukuran $8 \mathrm{~m} \times 8 \mathrm{~m} \times 4 \mathrm{~m}$

Model standar di atas adalah standar operasional dan prosedur dalam penggunaan perangkat bantu elektronik UNOUMI yang memiliki beragam fitur unggulan seperti:

a. Konsumsi daya rendah

b. Bentuk minimalis

c. Kemampuan menangani daya menengah

d. Standar suhu dan kelembaban terkunci program sesuai SOP budidaya jamur tiram

e. Dapat dialihfungsikan sesuai kebutuhan

\section{KESIMPULAN}

Pendekatan kesimpulan yang dapat diambil dalam implemntasi sistem adalah sebagai berikut:

a. Peranan standar operasional dan prosedur penerapan perangkat bantu UNOUMI dalam pengelolaan kumbung jamur moderen ini mampu meningkatkan produksi jamur itram secara signifikan

b. Ketidaksesuaian dengan standar oeprasional dan prosedur ini menjadikan produksi yang tidak signifikan

c. Sementara hasil terpantau dalam rentang uji 3 bulan dengan kondisi stabil, ideal utuk kumbung jamur dan fungsional harian yang baik dan sesuai harapan petani.

\section{SARAN}

Pengembangan standar sistem lanjut diperlukan dengan pantauan nilai riil menggunakan antarmuka kekinian seperti model aplikasi mobile dan pendataan jarak jauh nirkabel.

\section{UCAPAN TERIMA KASIH}

Penulis mengucapkan terima kasih kepada Fakultas Teknologi Informasi Universitas Stikubank (UNISBANK) Semarang yang telah memberi dukungan pendanaan terhadap penelitian ini. 


\section{DAFTAR PUSTAKA}

[1] Atmoko,Tjipto. 2012. Standar Operasional Prosedur (SOP) dan Akuntabilitas Kinerja Instansi Pemerintah. Jakarta: Skripsi

[2] Budihardjo, M. 2014.Panduan Praktis Menyusun SOP, Cetakan Pertama, Raih Asa Sukses, Jakarta.

[3] Hartatik, Indah Puji.2014. Buku Pintar Membuat S.O.P (Standard Operating Procedure), Flashbooks. Jogjakarta

[4] M. Sukur, E. Nurraharjo, H. Februariyanti, D. Budi Santoso, 2018, Penelitian " Pemodelan Sistem Pendukung Keputusan Guna Pemantauan Perubahan Data Riil pada sistem Kontrol Multi I/O ", Universitas Stikubank, Semarang.

[5] Sailendra, Annie. 2015. Langkah-Langkah Praktis Membuat SOP, Cetakan Pertama, Trans Idea Publishing, Yogyakarta.

[6] W. Hadikurniawati, 2010, "Perancangan Sistem Pendukung Keputusan Dengan Metode Analytical Hierarchy Process (AHP) Dan Analytical Network Process (ANP)", Universitas Diponegoro 